\title{
Foreign Direct Investment, Export Performance and Sustainable Development in Nigeria
}

\author{
Akintoye Victor Adejumo ${ }^{1}$ \\ ${ }^{1}$ Department of Economics, Obafemi Awolowo University, Ile-Ife, Nigeria \\ Correspondence: Akintoye Victor Adejumo, Department of Economics, Obafemi Awolowo University, Ile-Ife, \\ Nigeria. Tel: 234-803-402-6696. E-mail: adejumoakinvic@gmail.com; avadejumo@yahoo.com; \\ vadejumo@oauife.edu.ng
}

Received: December 26, 2017

Accepted: February 2, $2019 \quad$ Online Published: March 30, 2019

doi:10.5539/jsd.v12n2p110

URL: https://doi.org/10.5539/jsd.v12n2p110

\begin{abstract}
This study sets out to examine the role of manufacturing sector Foreign Direct Investment (FDI) in the quest for export sector diversification in Nigeria for sustainable development. This objective was achieved by estimating the effects of manufacturing sector FDI on manufactured goods export from Nigeria using the Autoregressive Distributed Lag estimating technique. The study discovered that FDI inflows into the country's manufacturing sector impacted negatively on manufactured exports in the short run. The short run result nevertheless gave way to a positive and significant influence of FDI on manufactured exports in the long run, indicating that this form of foreign capital is important for manufactured export promotion in Nigeria. The resulting long run positive FDIspillovers on export performance in Nigeria is in tandem with the neoliberal theoretical viewpoint that developing countries can rely on FDI as ladder to sustainable development. The findings suggest that sustainable development can be enhanced in Nigeria by exploiting the channel of positive spillovers from sector specific FDI inflows. The study concludes that with appropriate policy stance, one important way of pursuing the long run goal of sustainable development is to route FDI inflows in the direction of the country's manufacturing sector.
\end{abstract}

Keywords: autoregressive, capital, investment, industrial, spillover

\section{Introduction}

Globally, the classifications of most economies are patterned majorly after the level of industrialization within each economy. Specifically, a vibrant industrial base, real-sector competitive edge in manufacturing, a high degree of openness to international trade and investment are typical features of an industrialised or an industrialising economy. Theoretically, there are two major, but conflicting, explanations of industrial development through the channel of foreign direct investment (FDI). The first, which is the structuralist theory, prescribes import substitution industrialisation with a malign view of foreign direct investment (FDI), while the neoliberal perspective on the other hand, recommends export- oriented industrialisation with a strong benign opinion on FDIdevelopment impact. However, when neoliberal development thought outpaced structuralism, and tilted the stock of development literature in favour of globalization, conventional wisdom shifted towards the view that FDI was good for development. This implies that FDI can be seen as a major instrument for industrialising any economy. With dwindling official resource flows to assist the process of economic development, many developing countries had to embrace neoliberal policy prescriptions, embarked on capital account liberalisation, and turned to foreign private resources in order to fill the resource gap in their quest for economic development, which understandably begins with industrialisation.

Attraction to FDI inflow by developing economies is not without reasons. Basically, unlike loans, FDI can theoretically bring development capital without repayment commitments. Second, FDI is more resilient than other forms of private capital inflows in the event of economic crisis. This is evident in the Latin American debt crisis of the 1980s, during the Mexican crisis of 1994-95, and during the Asian financial crisis of 1997-98. Third, FDI offers unrivalled development opportunity capsule containing capital, contacts and managerial, financial and technological knowledge. This is a bundle of benefits that can, under appropriate conditions, spillover to host countries` firms. Despite these attributes, the controversy as to whether or not FDI can be relied on as resource flow for industrial development is still ongoing.

Empirical evidence remains contentious on whether or not developing countries find the FDI lead in the new 
profile of international capital flows for industrial development profoundly satisfactory. For instance, while some studies believe that FDI has advanced the course of industrial development through an augmentation of local resources and skills (Blomström and Kokko, 1997; Goldberg and Klein, 1999; Blonigen, 2001 and Swenson, 2003) other studies find contrary evidence and believe that FDI could threaten indigenous industrial development within host economies (Lipsey and Weiss, 1981; Gui-Diby and Renard (2015)). The argument of the later school of thought is based on the assumption that the expertise, experience, technology and resource advantage of investors associated with FDI leave local firms estranged in their own country.

Therefore, in order to ascertain the stance of FDI in promoting inclusive growth pattern (i.e. growth without rising poverty levels) in Nigeria, a standing channel of probe is the industrial sector and the manufacturing sector in particular. This is because productivity growth in manufacturing has positive implications for poverty reduction. Calculations from the Statistical Bulletin of the Central Bank of Nigeria (CBN) show that Nigeria's manufacturing sector only represents an average of 6.09 percent of total gross domestic product (GDP) in the decade of 1970 to 1979. The figure came up but insignificantly to 6.63 percent in the $1980 \mathrm{~s}$ and averaged 5.16 percent in the decade before as well as in the decade after the year 2000. In the more recent years 2010, 2011 and 2012, the manufacturing sector recorded a meagre 4.10 percent contribution to GDP. This is a far cry from the performance of the strong manufacturing sectors in other developing economies, where structural change has already occurred and where millions have been lifted out of poverty as a result of the activities in the manufacturing sector. For instance, as at 2012, manufacturing contributed 20 percent of GDP in Brazil, 34 percent in China, 30 percent in Malaysia, 35 percent in Thailand and 28 percent in Indonesia (Ogbu, 2012).

In agreement with the revelations from the $\mathrm{CBN}$ data described above, it has been noted that Nigeria is among a set of countries with negligible shares of production in manufacturing (Szirmai, 2009). It can be safely said that the poverty problem in Nigeria is partly traceable to the less than the desirable performance in the country's manufacturing sector. Yet, the manufacturing remains a cardinal area for providing quality employment and wages, correcting balance of payments problems, and reducing poverty, among others. Indeed, virtually all cases of high, rapid, and sustained economic growth in modern economic development have been associated with industrialisation, particularly growth in manufacturing production (Szirmai, 2009).

This study therefore focuses on a country- specific assessment of the role of foreign direct investment in national industrialisation efforts, with emphasis on data from Nigeria. This approach is important for the following reasons. First, given that export orientated industrialization is important for sustainable industrial development, the results of this study will evaluate the current position of Nigeria in relation to the country's goal of becoming one of the top twenty industrialized economies by the year 2020. Second, as empirical studies in FDI-growth nexus in Nigeria largely exist at the aggregate level, (Anyanwu 2011, Abubakar, 2013, Adejumo 2013, Akenbor 2014, Akinlo 2017) the sector focus of this study will provide sharper insights into FDI effects in the country for clearer policy intervention. This will enhance the ability to drive manufactured exports which is a leading indicator of industrial development, much needed for export diversification in the oil-exports-dependent economy.

The remainder of the paper is distributed as follows. The second section considers the theoretical framework that explains FDI spillover and the outcome of such spillover. The third section considers the research methodology, while the fourth section discusses the results from the empirical analysis. The fifth section concludes the paper by situating the result in the light of sustainable development.

\section{Literature Review}

\subsection{Theoretical Review}

A long tradition exists in development economics, which has an optimistic view of the effect of foreign direct investment (FDI) on industrial development in the host country. In this tradition, Multinational Enterprises (MNEs) are seen as agents that increase competition in the host economy, transfer modern technology, and help achieve a more efficient allocation of resources. Furthermore, it is argued that inward FDI pushes forward the process of industrial development by creating linkages with the rest of the economy (Latorre, 2008).

In theory, the various transfer channels of FDI spillovers that can benefit local industrial development can be grouped into two broad categories. These are productivity spillovers and market access (i.e. export) spillovers. Following Blomstrom and Kokko (1998), we define productivity spillovers as the increase in productivity or efficiency of the host country local firms as a consequence of the presence of MNEs. Productivity spillovers may be due to competition effect, demonstration effect, labour turnover and linkage effects. The first three could occur as intra- industry or horizontal spillovers while the fourth channel is necessarily an inter-industry or vertical spillover. Having recognised the competitive, demonstration and labour effects as productive spillovers from MNEs, of peculiar interest to this study is the linkage effect. MNEs can exert a significant influence on both the 
rate and characteristics of the process of growth and development in the industrial sector through the creation of forward and backward linkages with the host economy. As shown in figure 1, the linkage spillover channel emanates from the relationship that domestic firms establish, within the domestic market, between MNE's subsidiaries as their suppliers (backward linkages) or customers of intermediate inputs produced by MNEs subsidiaries (forward linkages), as pointed out, for instance by Lall (1980), and formalized by Rodriguez-Clare (1996), Markusen and Venables (1999), and Lin and Saggi (2004).

Backward linkages occur through knowledge transfers from foreign firms to local suppliers of inputs used by the former, that is, from downstream firms (MNEs) to upstream firms (local firms). Spillovers can occur through backward linkages via selection and scale economy effects. The selection effect is in operation when local suppliers get assistance from MNEs in management and organisational skills, and in setting up production, and when they have to meet the demand from foreign firms in the form of higher quality, price and delivery standards (Smarzynska, 2002). Another implication of backward linkages for spillover is the scale economy effect through demand by the MNEs for local intermediate inputs. This increased demand can spur domestic suppliers to expand production and thereby reduce average costs as a result of increasing returns to scale.

Forward linkage is FDI spillover channel through which benefits from upstream foreign firms to downstream domestic firms occur. In essence, it refers to the sale of the output of the MNE to domestic firms for use as inputs. There are incentives to transfer technology to domestic customer firms beyond contractual obligation to improve their efficiency and scales so that in return they buy more inputs from the MNE. Transferring technology to domestic firms in this way enables MNEs to gain new or bind existing customers. But the most evident link consists of the MNEs supply of a higher quality inputs and/or at a lower price to domestic producers of end-user customer goods (Markusen and Venables, 1999). Despite this, it is impossible to leave out the fact that the upgrade of the quality of production inputs may lead to an increase in prices. Where domestic firms lack the capacity to benefit from this upgrade of quality, they will suffer the negative effect associated with increased costs (Smarzynska, 2004).

A third linkage channel is also possible when MNEs subsidiaries and domestic firms operate within the same sector. This is referred to as horizontal linkages.

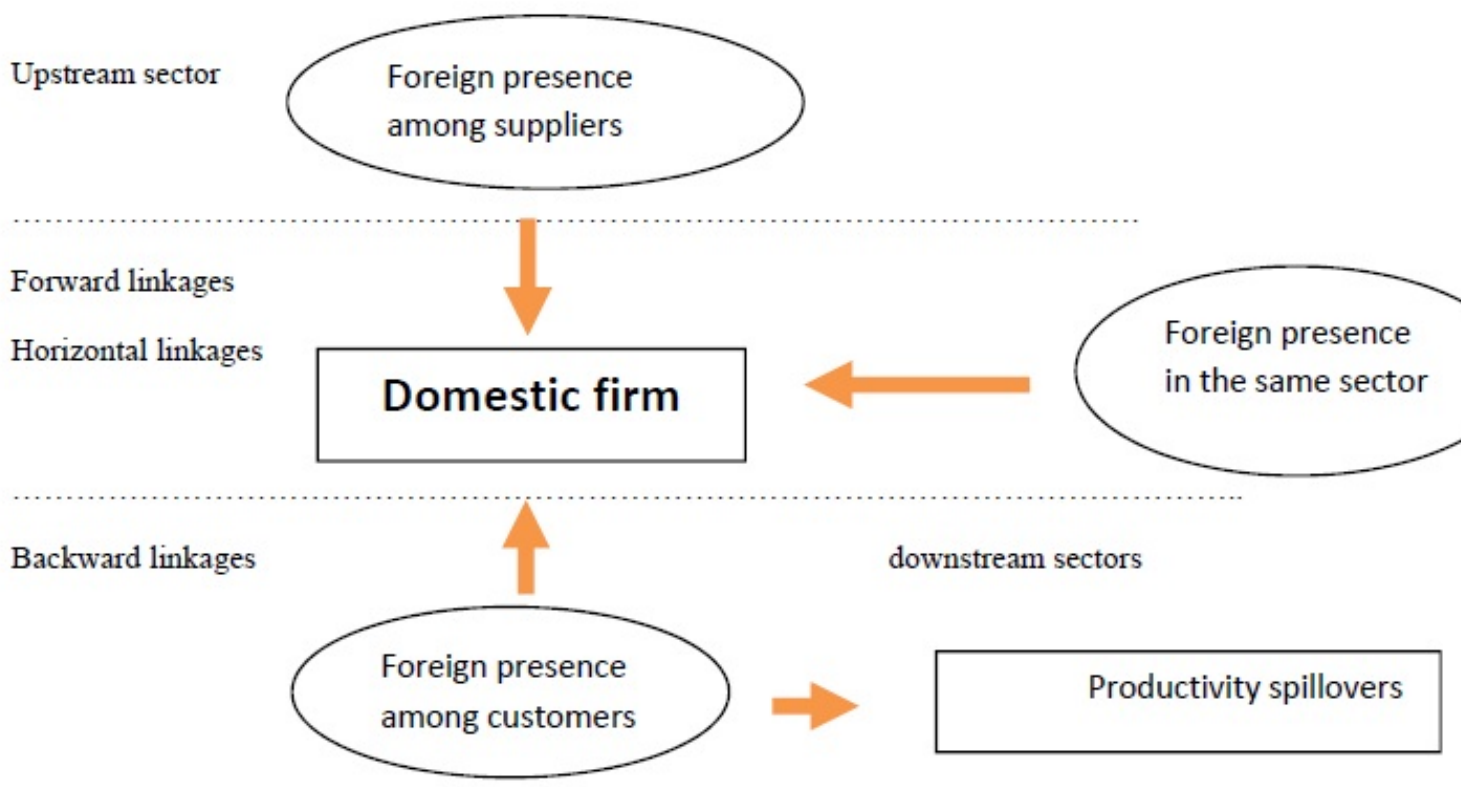

Figure 1. Backward and forward linkages

Source: Lesher and Miroudot (2008)

In a survey of empirical literature, Lall $(1981,1982)$ reports the presence of strong linkages between import substituting MNEs and local firms in large economies. The same is said to be true of MNEs that gradually change from import substitution to export oriented production (Kjetil, Kind, \& Nordas, 2002). However, compared to supplier-contacts (backward linkage) and the forward-linkage (customer-contacts), there is no doubt that the 
presence of MNEs are capable of generating productivity spillovers. However, this could be established through the strong linkages identified of MNEs supporting local production, and adjusting their ISI policies to promoting exports.

Perhaps the most prevalent version of the beneficial conceptualization of FDI begins with a stylized description of how FDI may help the host country to break out of the vicious cycle of underdevelopment, perceived as rising level of industrialization. In the industrialization theory of FDI, this type of investment represents not simply a transfer of capital, but the transfer of a "package" of ownership advantages in which capital, management, international market access and new technology are combined (Hymer, 1976). Through FDI, MNEs may play their role in the industrial development of the host economy through the possible channels for transmission of spillover benefits derived from their (MNEs') ownership advantages. Markusen and Venables (1999) stated in their model that MNEs might have affected the domestic industry of the host country positively by developing the linkages with the local firms. According to Lall (1980), the MNEs had a positive effect on the local firms by demanding the high quality inputs; providing the technology; the information and the training, as well as the access to international market.

\subsection{Empirical Review}

Multinational enterprises (MNEs) not only generate international flows of foreign direct investment, but are also responsible for substantial trade flows across national boundaries. According to UNCTAD (2004), trade activities by MNEs explain over 60 percent of world exports. Since MNEs account for a large proportion of world trade, it is plausible to infer a close relationship between FDI inflows and trade. Results of empirical investigation into the trade effects of FDI, however, appear unsettled. In the case of imports, evidence exists for both positive and negative effects of FDI (Blomström and Kokko, 1997; Goldberg and Klein, 1999; Blonigen, 2001 and Swenson, 2003). Without correcting for endogeneity effects from host market characteristics, Lipsey and Weiss $(1981 ; 1984)$ found a positive relationship between FDI and imports. Even after correcting for endogeneity, Bajo-Rubio and Montero-Muñoz (2001) also discovered a positive relationship between FDI and imports. However, Gruber and Mutti (1991) using data similar to Lipsey and Weiss (1981) found an insignificant but negative relationship between FDI and imports.

It remains cloudy whether MNEs tend to generate trade deficits or surpluses in the host economy. In the case of exports, the balance of empirical evidence is that, for developed economies, FDI inflows increase exports of the host economy (Blomström and Kokko, 1997; Lipsey, 2002; Greenaway and Kneller, 2007).

Despite the empirical suggestion above, it is important to consider the relationship between FDI and trade via- $a$ vis the horizontal or vertical form of FDI. As noted by Latorre (2008), for horizontal FDI, trade and FDI are seen as substitutes but for vertical FDI, the connection between FDI and trade appear complimentary. Although Markusen (2002) observed that FDI flows among developed countries are mainly horizontal, he nevertheless noted the strategic importance of vertically integrated firms in some of these advanced economies. This is in agreement with Carr, Markusen and Maskus (2001) which concludes the concurrent occurrence of horizontal and vertical FDI by multinational enterprises. In Blonigen (2001), Head and Ries (2001), and Swenson (2004) pieces of empirical evidence suggest that FDI expands imports of intermediate inputs from the host economy but decreases imports of finished products. In the light of this empirical evidence, and given the connection between FDI and trade noted by Lattore (2008), then vertical FDI may lead low income countries to enter the global production chains of MNEs, by producing intermediate manufactures with high value added for the export market. Similarly, horizontal FDI can help low income countries reduce the import bill. For a developing economy in search of export diversification for sustainable income growth, an important issue to address with regard to FDI inflows is the type of trade that will emanate from MNEs activities in consonance with domestic production, which will ultimately promote overall exports. In view of the foregoing, this country-specific study on Nigeria is aimed at enriching the empirical literature on the connection between FDI and exports in the search for sustainable development in a low income economy. Examining the manufacturing export orientation of the domestic economy is significant, in determining the extent to which the presence of FDI has advanced the course of sustainable industrial development in Nigeria.

\section{Research Methodology}

\subsection{Model Formulation.}

To test the impact of FDI on exports, we followed the proposition of Safdari and Motiee (2011) on the determinants of non- oil exports but with modifications on the variables. Replacing non-oil exports with manufactured exports (MEX), we employ a model that takes into consideration some trade reform indicators which include real exchange rate (RER), trade liberalization (TLI), and external market access (MKT) in addition to manufacturing foreign direct investment (MFDI). 
Accordingly, we employ the following model specification:

The reduced form of equation is:

$$
M E X_{t}=f(M F D I, R E R, T L I, M K T)
$$

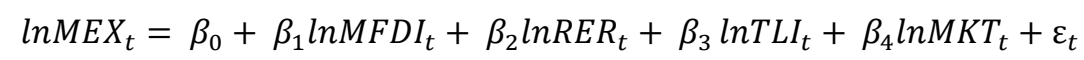

where $\varepsilon_{t}$ is the error term.

A priori, it is expected that $\beta_{1}, \beta_{3}, \beta_{4}$, will be positive, while $\beta_{2}$ will be negative.

The ARDL model of equation (1) above is specified as follows:

$$
\begin{gathered}
\beta_{0} \sum_{i=1}^{q} \beta_{1 i} \Delta \ln \left(M E X_{t-i}\right)+\sum_{i=0}^{q} \beta_{2 i} \Delta \ln \left(M F D I_{t-i}\right)+\sum_{i=0}^{q} \beta_{3 i} \Delta \ln \left(R E R_{t-i}\right)+\sum_{i=0}^{q} \beta_{4 i} \Delta \ln \left(T L I_{t-i}\right)+ \\
\sum_{i=0}^{q} \beta_{5 i} \Delta \ln \left(M K T_{t-i}\right)+\beta_{6} \ln \left(M E X_{t-1}\right)+\alpha_{7} \ln \left(M F D I_{t-1}\right)+\alpha_{8} \ln \left(R E R_{t-1}\right)+\alpha_{9} \ln \left(T L I_{t-1}\right)+ \\
\alpha_{10} \ln \left(M K T_{t-1}\right)+\varepsilon_{t}
\end{gathered}
$$

where $\Delta$ is the first different operator, $q$ is the optimal lag length, $\beta_{1}, \beta_{2}, \beta_{3}, \beta_{4}$ and $\beta_{5}$ represent short-run dynamics of the model and $\beta_{6} \ldots \ldots \ldots \beta_{10}$ represent the long-run elasticities. An error-correction version of equation (2) is given as:

$$
\begin{gathered}
\Delta I n M E X t=\beta_{0} \sum_{i=1}^{q 1} \beta_{1 i} \Delta I n \operatorname{MEX}_{\mathrm{t}-\mathrm{i}}+\sum_{t=0}^{q 2} \beta_{2 \mathrm{i}} \Delta I n \mathrm{MFDI}_{\mathrm{t}-\mathrm{i}}+\sum_{t=0}^{q 3} \beta_{3 \mathrm{i}} \Delta I n \mathrm{RER}_{\mathrm{t}-\mathrm{i}}+\sum_{t=0}^{q 4} \beta_{4 \mathrm{i}} \Delta I n \mathrm{TLI}_{\mathrm{t}-\mathrm{i}}+ \\
\sum_{t=0}^{q 5} \beta_{5 \mathrm{i}} \Delta I n \mathrm{MKT}_{\mathrm{t}-\mathrm{i}}+\lambda \mathrm{ECM}_{\mathrm{t}-\mathrm{i}}+\varepsilon_{\mathrm{t}}
\end{gathered}
$$

where $\mathrm{q}_{1}, \mathrm{q}_{2}, \mathrm{q}_{3}, \mathrm{q}_{4}, \mathrm{q}_{5}$ depict optional lag lengths, $\lambda$ is the speed of adjustment parameter and ECM represents the error correction term derived from the long-run relationship as given in (3) above.

\subsection{Estimation Technique}

The unit root test was performed on the variables. The Augmented Dickey-Fuller (1979) and Philip-Perron (1988) tests were performed to estimate the unit root properties of the variables. In order to determine the long-run relationship as given in equation (2), we conducted bounds test of equation (2) using F-statistic with two bounds, i.e. lower bound and upper bound. The null hypothesis assumes no co-integration among variables. If the value of F-statistic is greater than the upper bound then the null hypothesis will be rejected, and if it is less than lower bound then null hypothesis will be accepted. If it falls between the lower and upper bounds, the test is inconclusive. The optimal lag-length used was determined by the Schwarz Bayesian Criterion (SBC).

Also, using data covering 1970-2014, the study used Auto Regressive Distributed Lag Approach to establish the long run relationship among the variables and the short run dynamics of the model, using equations (3) and (4).

\subsection{Definition and Measurement of Variables}

i. MEX is the share of manufactured exports as a percentage of total merchandise exports. The data was obtained from World Development Indicators (WDI), 2015.

ii. MFDI is the cumulative foreign private investment in the manufacturing sector. The data was obtained from Central Bank of Nigeria Statistical Bulletin, 2015.

iii. RER is the nominal exchange rate adjusted for relative price levels. To calculate the real exchange rate we used the following formula:

$$
\text { Real exchange rate }=\text { Norminal Exchange Rate } \mathrm{x} \frac{\text { Foreign country's price level }}{\text { Home country's price level }}
$$

Where, foreign country is chosen to be the USA, being Nigeria's largest trading partner and the benchmark economy in the world. The home country is Nigeria. The data was obtained from WDI.

iv. TLI is the trade liberalization index defined as the total merchandise imports divided by GDP. The data was obtained from WDI, 2015.

v. MKT is the GDP per capita at constant prices obtained from WDI, 2015.

The dependent variable is the value of manufacturing exports (MEX), RER represents the real exchange rate. In light of this, the coefficient of $\beta_{2}$ is expected to be negative.

\subsection{Sources of Data}

The various data needed for the study were obtained from publications of the World Bank, International Financial Statistics, Africa Development Indicator, World Development Indicators, United Nations Conference on Trade 
and Development as well as the Central Bank of Nigeria Statistical Bulletin for various years.

\section{Empirical Results and Discussions}

\subsection{Descriptive Analysis for the Model}

Table 1 reports the descriptive statistics of data employed in determining the performance of manufacturing exports in Nigeria. For the model, data on market (MKT) and manufacturing foreign direct investment (MFDI) have been transformed into their logarithm form before been applied for analysis; while the data for manufactured exports (MEX), Trade Liberalisation (TLI) and real exchange rate (RER) remained in their original percentage forms.

Table 1. Determinants of manufactured exports

\begin{tabular}{lccccc}
\hline Statistic & MEX & MFDI & RER & TLI & MKT \\
\hline Mean & 1.247 & 8.441727 & 139.2965 & 22.63956 & 12.39147 \\
Median & 0.620 & 8.198914 & 133.3257 & 20.92523 & 12.38403 \\
Maximum & 6.686 & 12.29916 & 279.6832 & 47.55208 & 12.79557 \\
Minimum & 0.023 & 3.160399 & 47.30908 & 8.441836 & 12.05759 \\
Std. Dev. & 1.565 & 2.450253 & 72.85454 & 8.581729 & 0.221745 \\
Skewness & 1.873 & -0.319262 & 0.340963 & 0.580274 & 0.211169 \\
Kurtosis & 6.027 & 2.471274 & 1.81427 & 2.977863 & 1.615018 \\
Jarque-Bera & $41.570^{* *}$ & $1.231346^{\neq}$ & $3.352170^{*}$ & $2.414024^{*}$ & $3.756308^{*}$ \\
Probability & 0.000 & 0.540 & 0.187105 & 0.29909 & 0.152872 \\
Sum & 53.606 & 362.994 & 5989.75 & 973.5012 & 532.8334 \\
Sum Sq. Dev. & 102.815 & 252.157 & 222926.9 & 3093.135 & 2.065178 \\
Observations & 43 & 43 & 43 & 43 & 43 \\
\hline
\end{tabular}

Critical values of $\chi^{2}$ at 5 percent and 1 percent levels are 5.99 and 9.21 respectively. ${ }^{*}\left({ }^{* *}\right)$ denotes the acceptance of the null hypothesis that the variables are normally distributed at 5 percent and (1 percent) significant level, while $(\neq)$ implies the rejection of normality at all levels.

From Table 1, all data are normally distributed at 5 percent level of significance. The normality assumption is further buttressed by the nearness of the mean and median values for these series. The closer the mean and median values of a data series, the greater the probability that such series will be normally distributed; hence, all the series displayed a high level of consistency as their mean and median values are perpetually within the maximum and minimum values of these series. Besides, the standard deviation revealed that actual data in the series are not really different from their mean value. The skewness and kurtosis statistics provide useful information about the symmetry of the probability distribution of the various data series as well as the thickness of the tails of these variables.

\subsection{Unit Root Test}

It is not unusual to discover that most time-series variables are non-stationary in their levels and that several of these variables are therefore, represented in their first difference. These time-series are therefore said to be integrated of order one and are denoted by I (1), while those that remain at level can be denoted by I (0). The level of some variables can be so large or small that they do not revert to their mean as expected, hence the need for stationarity test which is also known as unit root test. 
Table 2. Unit root test for the model (dependent variable- manufactured exports)

\begin{tabular}{|c|c|c|c|c|c|c|c|c|c|}
\hline \multirow[b]{2}{*}{ Variable } & \multicolumn{2}{|c|}{$\mathrm{ADF}^{*}(1 \mathrm{Lag})$} & \multirow[t]{2}{*}{$d^{*}$} & \multicolumn{2}{|c|}{ PP* (3 Lags) } & \multirow[t]{2}{*}{$d^{*}$} & \multicolumn{2}{|c|}{ KPSS*(3 Lags) } & \multirow[b]{2}{*}{$d^{*}$} \\
\hline & $\begin{array}{c}\text { With } \\
\text { Constant } \\
\text { (No trend) }\end{array}$ & $\begin{array}{c}\text { With } \\
\text { Constant \& } \\
\text { trend }\end{array}$ & & $\begin{array}{c}\text { With } \\
\text { Constant } \\
\text { (No trend) }\end{array}$ & $\begin{array}{c}\text { With } \\
\text { Constant \& } \\
\text { trend }\end{array}$ & & $\begin{array}{c}\text { With } \\
\text { Constant } \\
\text { (No } \\
\text { Trend) } \\
\end{array}$ & $\begin{array}{c}\text { With } \\
\text { Constant } \\
\text { \& Trend }\end{array}$ & \\
\hline MEX & -1.702 & -1.131 & $\mathrm{I}(1)$ & -3.100 & -4.9329 & $\mathrm{I}(0)$ & 0.748 & 0.251 & $\mathrm{I}(0)$ \\
\hline$\triangle \mathrm{MEX}$ & -5.028 & -5.862 & & -20.69 & -22.539 & $\mathrm{I}(1)$ & 0.265 & 0.243 & $\mathrm{I}(1)$ \\
\hline MFDI & -1.544 & -0.729 & $\mathrm{I}(1)$ & -1.725 & -1.725 & $\mathrm{I}(1)$ & 0.428 & 0.145 & $\mathrm{I}(1)$ \\
\hline$\triangle \mathrm{MFDI}$ & -6.292 & -6.602 & & -6.292 & -6.602 & & 0.304 & 0.101 & \\
\hline RER & -1.929 & -2.814 & $\mathrm{I}(1)$ & -2.105 & -2.454 & $\mathrm{I}(1)$ & 0.441 & 0.077 & $\mathrm{I}(1)$ \\
\hline$\triangle \mathrm{RER}$ & -5.336 & -5.271 & & -5.328 & -5.271 & & 0.060 & 0.058 & \\
\hline TLI & -3.071 & -3.174 & $\mathrm{I}(0)$ & -3.071 & -3.146 & $\mathrm{I}(0)$ & 0.182 & 0.152 & $\mathrm{I}(0)$ \\
\hline$\Delta \mathrm{TLI}$ & -8.028 & -8.071 & $\mathrm{I}(1)$ & -8.275 & -9.395 & $\mathrm{I}(1)$ & 0.287 & 0.137 & \\
\hline MKT & -0.227 & -0.213 & $\mathrm{I}(1)$ & -0.685 & -0.419 & $\mathrm{I}(1)$ & 0.190 & 0.190 & $\mathrm{I}(1)$ \\
\hline$\Delta \mathrm{MKT}$ & -5.521 & -6.001 & & -5.604 & -6.003 & & 0.312 & 0.136 & \\
\hline $\begin{array}{l}\text { Mackinnon } \\
\text { critical } \\
\text { values: } \\
\text { Level }\end{array}$ & & & & & & & $\begin{array}{c}\text { Asymptot } \\
\text { ic Critical } \\
\text { Values }\end{array}$ & $\begin{array}{c}\text { Asymptot } \\
\text { ic Critical } \\
\text { Values }\end{array}$ & \\
\hline $1 \%$ & -3.610 & -4.212 & & -3.611 & -4.212 & & 0.739 & 0.216 & \\
\hline $5 \%$ & -2.939 & -3.530 & & -2.939 & -3.528 & & 0.463 & 0.146 & \\
\hline $10 \%$ & -2.609 & -3.198 & & -2.608 & -3.196 & & 0.347 & 0.119 & \\
\hline \multicolumn{10}{|l|}{$1^{\mathrm{st}}$} \\
\hline \multicolumn{10}{|l|}{ Difference } \\
\hline $1 \%$ & -3.616 & -4.219 & & -3.616 & -4.219 & & & & \\
\hline $5 \%$ & -2.941 & -3.533 & & -2.941 & -3.533 & & & & \\
\hline $10 \%$ & -2.609 & -3.198 & & -2.609 & -3.198 & & & & \\
\hline
\end{tabular}

Source: Self-computation using E views 9.0

Notes: * d denotes decision about the respective order of integration.

From Table 2, the results of the Augmented Dickey Fuller, Phillip Perron , and Kwiatkowski-Philips-Schmidt-Shin tests at level and first difference equally reveal that the logarithms, ratios and percentages of all the variables are stationary at first difference given the 5 and 10 percent significance levels. Hence, the variables are adaptable for the Autoregressive Distributed Lag (ARDL) estimation technique.

\subsection{ARDL Results: FDI and Manufactured Exports in Nigeria}

The ARDL results on the effects of FDI on manufactured exports are shown in Tables 3 to 5 . Before estimating the ARDL test, we first examine the existence of a level relationship among the variables used for our analysis.

Table 3 reveals the computed F-statistic to select optimal lag-length in the model. According to Pesaran et al. (2001), with lag of order 1 the lower and upper bound values at 95 percent significance level are 2.5302 and 3.7843 respectively and the lower and upper bound values at 90 percent significance level are 2.0464 and 3.1839 respectively. Thus, we can conclude that the computed value of F-statistic (6.2893) is greater than the upper bound values of F-statistic both at 95 percent and 90 percent significance levels. This helps us to reject the null hypothesis of no long run relationship. Therefore, we conclude that there is long-run relationship among the variables. 
Table 3. F-statistic for testing the existence of long-run relationship of ARDL $(1,0,0,0,0)$ model

\begin{tabular}{llllll}
\hline Order of Lag & F Statistics & 95\% Lower Bound & $95 \%$ Upper Bound & $90 \%$ Lower Bound & $90 \%$ Upper Bound \\
\hline 1 & 6.289 & 2.508 & 3.784 & 2.046 & 3.184 \\
\hline
\end{tabular}

Source: Self-computation using Micro fit 5.0

Note: Dependent Variable- Growth of Manufactured Exports (LNMEX)

The optimal lag length of the variables included in the ARDL Model was selected based on the Schwarz Bayesian Criterion (SBC). Table 4 presents the result of the long run relationship of the selected ARDL Model $(1,0,0,0,0)$ using the SBC.

Table 4 reveals that MFDI impacted positively on the manufactured export in Nigeria. The t-statistic valued at 2.6559 revealed that a capital inflow to the manufacturing sector in the long-run has a positive significance on manufactured exports. This shows that a percentage rise in MFDI leads to rise in manufactured exports by 0.39 percent. Real effective exchange rate is negatively related to manufactured exports. However, the coefficient is not statistically significant. In a similar vein, market (proxied by per capita income) has insignificant negative effect on manufactured exports in the long-run. Similarly, trade liberalization has an insignificant negative effect on manufactured exports performance in Nigeria. The result shows that a 1 percent rise in trade liberalisation will reduce manufactured export growth by 0.057 percent. Also REER showed that a unit appreciation in reel effective exchange rate will decrease MEX by 3.4 percent.

Table 4. Long run coefficients of ARDL $(1,0,0,0,0)$ model

\begin{tabular}{lllll}
\hline Regressor & Coefficient & Standard Error & T-Ratio & Probability \\
\hline LNMFDI & 0.395 & 0.149 & $2.656^{*}$ & 0.012 \\
REER & -0.034 & 0.099 & -0.348 & 0.734 \\
LNMKT & -0.003 & 0.0044 & -0.640 & 0.526 \\
LNTLI & -0.057 & 0.034 & -1.683 & 0.101 \\
\hline
\end{tabular}

Note, ${ }^{*}$ and ${ }^{* *}$ show significance levels at 5 percent and 10 percent respectively. Dependent Variable- Growth of Manufactured Exports (LNMEX); Selected based on Schwarz Bayesian Criterion

Source: Self-computation using Micro fit 5.0

From the result of error correction representation of the selected ARDL model shown in Table 5 below, the coefficients of the variables with (d) sign show the short run elasticities. The variables behave in the same way with the ARDL estimates in the long run, in terms of the a priori expectations, level of significance and impacts on manufactured exports. The coefficient of error correction term (-0.59479) is significant both at 1 percent and five percent levels. Highly significant negative sign of the error correction terms (with t-ratio at -5.3006) reinforces the existence of long run relationship among the variables. However, the speed of adjustment from the previous year's disequilibrium in manufactured export to current year's equilibrium is about 59.4 percent.

Specific results of the explanatory variables revealed that all the variables had negative effects on the growth of manufactured exports in Nigeria except trade liberalization, TLI. Unlike the long-run relation, MFDI with a t-ratio $=3.2082$, had a significant negative effect on manufactured export in the short-run, such that a percentage rise in capital inflow to the manufacturing sector (MFDI) caused manufactured exports to fall significantly by 0.39 percent. But the a priori expectation between real exchange rate and manufactured exports remains; with a t-ratio of 0.654 , a one percentage increase in real exchange rate will cause an insignificant decline in manufactured exports by 0.002 percent. Similar to the long-run estimates, the variable used to depict market performance maintained a consistent negative relationship with manufactured exports; such that a one percent rise in market value depreciates manufactured exports insignificantly by 0.02 percent (where t-ratio $=0.476$ ). In addition to these negative interactions, although insignificant (with t-ratio $=1.616$ ), it was also discovered that trade liberalization had a positive effect on manufactured exports; in that a one percent increase in trade liberalization causes manufactured exports to rise by 0.034 percent.

The explanatory power of the model is indicated by the value $\mathrm{R}^{2}=0.55314$. It can be said that the extent to which the independent variables explains the growth of manufactured exports is 55 percent; while with the adjustment of 
some properties, the adjusted $\mathrm{R}^{2}$ puts the power of the explanatory viable at 49 percent An examination of the econometric result shows that the overall fit is averagely satisfactory and the F-statistic valued at 11.14 is significant at 5 percent level. In addition, the Durbin-Watson Statistic of 2.09 showed that there is no autocorrelation amongst the independent variables used to explain the growth of manufactured exports.

Table 5. Error correction representation of the selected ARDL $(1,0,0,0,0)$ model

\begin{tabular}{lcccc}
\hline Regressor & Coefficient & Standard error & T-Ratio & Probability \\
\hline dLNMFDI & -0.390 & 0.122 & $-3.208^{*}$ & 0.003 \\
dREER & -0.002 & 0.003 & -0.654 & 0.730 \\
dLNMKT & -0.020 & 0.058 & -0.476 & 0.730 \\
dLNTLI & 0.034 & 0.021 & 1.616 & 0.115 \\
ECM(-1) & -0.595 & 0.112 & $-5.300^{*}$ & 0.000 \\
\hline
\end{tabular}

R-squared $\quad 0.553 \quad$ R-Bar-Squared 0.49108

S.E. of Regression $\quad 1.011$ F-stat. $\quad F(4,370) 11.1405(0.000)$

Mean of Dependent Variable 0.051 Schwarz Bayesian Criterion -68.0273

DW-statistic 2.0927

Selected based on Schwarz Bayesian Criterion

Note, * shows significance at 5 percent significance level; Dependent Variable- Growth of Manufactured Exports (LNMEX)

Source: Self computation using Micro fit 5.0

Table 6 indicates the underlying ARDL equation passes the diagnostic tests on normality; but it failed the heteroscedasticity and serial correlation test at 5 percent. However, according to Shrestha and Chowdhury (2005), since the time series constituting the ARDL equation are potentially of mixed order of integration, i.e., I ( 0 ) and I (1), it is natural to detect heteroscedasticity. The stability of the long-run coefficients, along with the short run dynamics of the estimated ARDL model were confirmed with the test of Cumulative Sum of Recursive Residuals (CUSUM) and Cumulative Sum of Squares Recursive Residuals (CUSUMQ). Figure 2 and 3 present the plots of the CUSUM and CUSUMQ based on the Schwarz Bayesian Criterion and show that the plot remains within critical bounds at 5 percent level of significance. This accepts the null hypothesis that all coefficients and the ECM are stable. Thus the model can be said to be structurally stable and is valid for predictive purposes, having satisfied the required conditions.

Table 6. ARDL-VECM model diagnostic test

\begin{tabular}{lc}
\hline Test Statistics & \multicolumn{1}{c}{$\operatorname{LM}\left(\chi^{2}\right)$} \\
\cline { 2 - 2 } Serial Correlation & $\chi^{2}(1)=0.849(0.357)$ \\
Functional Form & $\chi^{2}(1)=1.387(0.239)$ \\
Normality Applicable & $\chi^{2}(2)=73.286(0.000)$ \\
Heteroscedasticity & $\chi^{2}(1)=0.116(0.914)$ \\
\hline
\end{tabular}

Notes: Selected based on Schwarz Bayesian Criterion;

Dependent Variable- Growth of Manufactured Exports (LNMEX) 


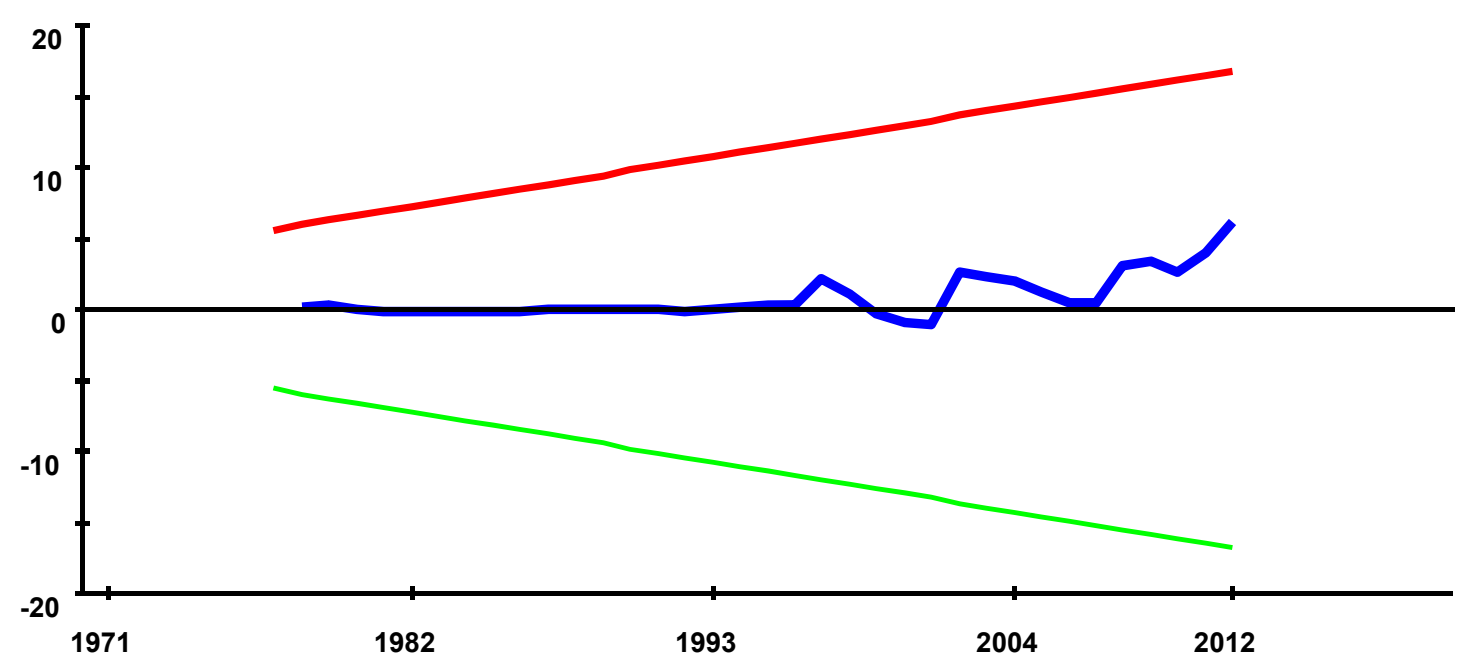

The straight lines represent critical bounds at $5 \%$ significance level

Figure 2. Plot of cumulative sum of recursive residuals

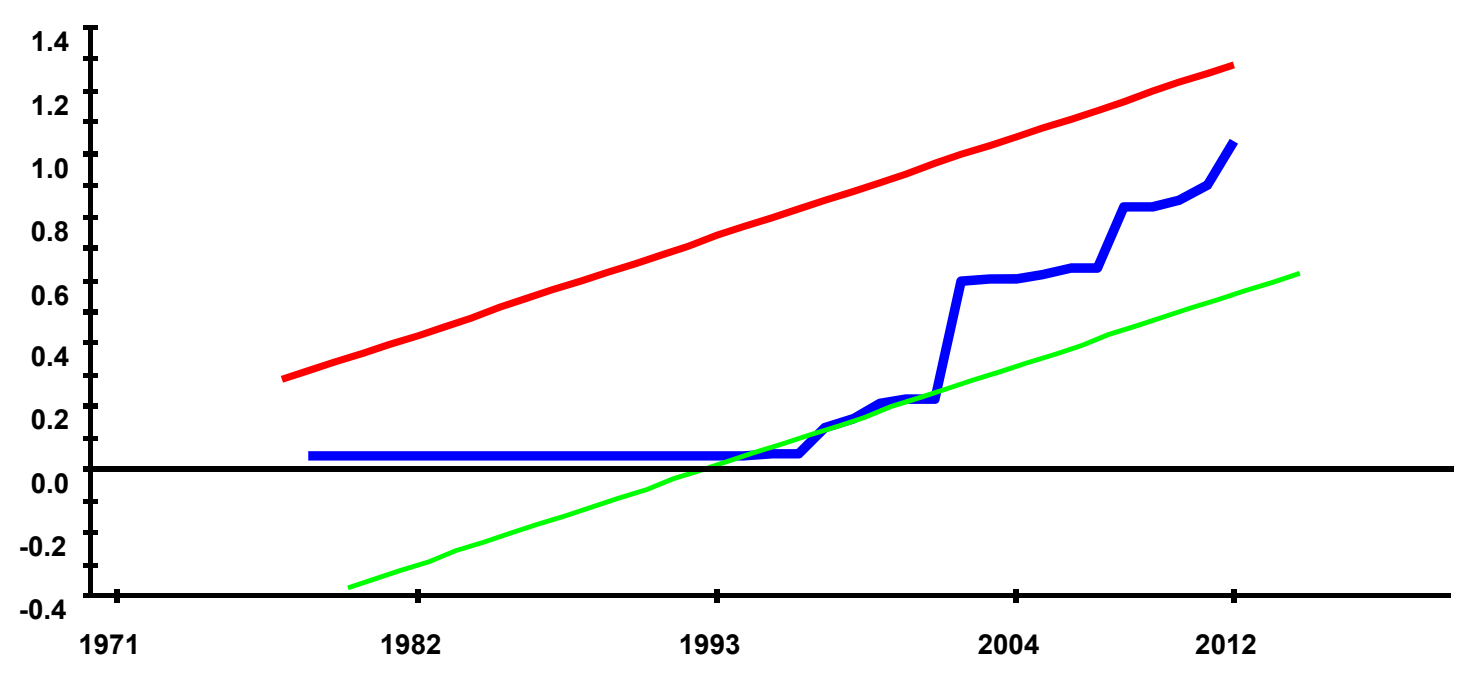

The straight lines represent critical bounds at $5 \%$ significance level

Figure 3. Plot of cumulative sum of squares of recursive residuals

In terms of export of the manufacturing sector in Nigeria, it was found that only manufacturing FDI (MFDI) had the expected relevance on the manufacturing sector. MFDI came up with the predicted positive sign and was significant in the long-run. The effect of the market (MKT), which is a representation of the level of 
development, came up with an insignificant and negative effect on manufactured exports. Similarly, trade liberalisation also had an insignificant and negative effect on manufactured exports. Although, the a priori expectation of an inverse relationship between manufactured exports and real exchange rate occurred, nonetheless, this relationship appeared insignificant. This implies that a decrease in the value of exchange rate will cause manufactured exports to be cheaper and facilitate the sale of these products in the international market. Despite the insignificant nature of most of the variables explaining the growth of manufactured exports, FDI is very important in generating and promoting exports in the Nigerian manufacturing sector. This finding is consistent with those of Blake and Pain (1994), Cabral (2010) and Prasanma (2010) for India. However, while examining regional export orientation and FDI, Wen (2005) found mixed results for China. He found that FDI inflows contributed positively to export growth in East China, unlike the negative impact of FDI inflow for Central China.

\section{Conclusion and Application of Result to Sustainable Development}

The study suggests that on the industrial development indicator of manufactured exports, FDI in the manufacturing sector impacted negatively in the short run. Although this negative impact was significant and contradicts theoretical expectations, it nevertheless reverts into a positive and significant influence on manufactured exports in the long run, as expected in theory. The implications of the findings of this study in terms of sustainable development financing are as follows:

- In the short-run, the inflow of FDI into the manufacturing sector in Nigeria appears to benefit foreign firms more than domestic ones. FDI from multinational corporations could have operated as export-substituting platforms in Nigeria, with a depressing effect on local manufacturing production for the international market. Thus, the short-run impact of FDI on manufactured exports does not stimulate increase in domestic income growth for sustainable development in the country.

- However, the theoretical spillover effects of manufactured FDI can create benefits for the Nigerian economy in the long-run. As empirical evidence from this study shows, FDI inflows into the manufacturing sector have positive and statistically significant impact on manufactured exports in the long -run. This creates exploitable prospects for sustainable income generation through export base diversification for the Nigerian economy.

Thus we can conclude that there are long run positive spillovers of FDI inflows into the manufacturing sector in Nigeria. The practical application of this research is that, given the continuing search for FDI to boost government revenue for sustainable development projects, policy makers should create and implement policies in favour of manufacturing FDI to enhance manufactured exports.

\section{References}

Abubakar, M. A. (2013). An Inquiry into the Determinants of Foreign Direct Investment in Nigeria. European Scientific Journal, 9(25), 293-308.

Adejumo, A. V. (2013). Foreign Direct Investments and Manufacturing Sector Performance in Nigeria, (1970-2009). Australian Journal of Business and Management Research, 3(4), 39.

Akenbor, C., \& Tennyson, O. (2014). Determinants of Foreign Direct Investment in a Democratic Society: The Nigerian Experience. Business and Management Review, (4), 282-294

Akinlo A. E. (2017). Determinants of Foreign Direct Investment in Nigeria: A Markov Regime-Switching Approach. Review of Innovation and Competitiveness, 3(1), 21-48. https://doi.org/10.32728/ric.2017.31/2

Anyawu, J. C. (2011). Determinants of Foreign Direct Investment Inflows into Africa, 1980-2007. African Development Bank Group, Working Paper, No. 136.

Bajo-Rubio, O., \& Montero-Muñoz, M. (2001). Foreign direct investment and trade: A causality analysis. Open Economies Review, 12, 305-323. https://doi.org/10.1023/A:1011185507169

Blake A., \& Pain, N. (1994). Investigating Structural Change in U.K Export Performance: The Role of Innovation and Direct Investment. Discussion paper no 71 Natl. Inst. Econ. Soc. Res., Paper No. 7

Blomström, M., \& Kokko, A. (1997). How Foreign Investment Affects Host Countries. Policy Research Working Paper, No.1745, The World Bank.

Blomström, M., \& Kokko, A. (1998). Multinational Corporations and Spill-overs. Journal of Economic Surveys, $12(2), 1-31$.

Blonigen, B. A. (2001). In Search of Substitution between Foreign Production and Exports. NBER Working Paper 
No. 7154, June 1999. LEL No F21, F23. https://doi.org/10.1016/S0022-1996(00)00066-0

Blonigen, B. A., Davies, R. B., \& Head, K. (2003). Estimating the Knowledge-capital Model of the Multinational Enterprise: Comment. American Economic Review, 93, 980-994. https://doi.org/10.1257/000282803322157214

Cabral, R. (2010). The PIGS'External Debt Problem. VoxEU.org, May 8.

Carr, D. J., Markusen, J. R., \& Maskus, K. (2003). Estimating the Knowledge-capital Model of the Multinational Enterprise: Reply. American Economic Review, 93, 995-1001. https://doi.org/10.1257/000282803322157223

Dickey, D. A., \& Fuller, W. A. (1979). Distribution of the Estimators for Autoregressive Time Series with a Unit Root. Journal of the American Statistical Association, 74(366a), 427-431.

Goldberg, L., \& Klein, M. (1999). International Trade and Factor Mobility: An Empirical Investigation, Working Paper No. 7196, National Bureau of Economic Research.

Greenaway, D., \& Kneller, R. (2007). Firm Heterogeneity, Exporting and Foreign Direct Investment. Economic Journal, 117, 134-161. https://doi.org/10.1111/j.1468-0297.2007.02018.x

Grubert, H., \& Mutti J. (1991). Taxes, Tariffs and Transfer Pricing in Multinational Corporate Decision Making. Review of Economics and Statistics, 73, 285-293. https://doi.org/10.2307/2109519

Gui-Diby, S. L., \& Renard, M. F. (2015). Foreign Direct Investment Inflows and the Industrialization of African Countries. World Development, 74, 43-57. https://doi.org/10.1016/j.worlddev.2015.04.005

Head, K., \& Ries, J. (2001). Overseas Investment and Firm Exports. Review of International Economics, 9, 108-22. https://doi.org/10.1111/1467-9396.00267

Hymer, S. H. (1976). The International operations of national firms: A study of direct foreign investment. The MIT Press, Cambridge, MA.

Jutta, G. (2002). The significance of FDI for innovation activities within domestic firms: the case of Central East European economies. Discussion papers Nr,162, Halle Institute for Economic Research.

Kjetil, B., Kind, H. J., \& Nordas, H. K. (2002). The Role of FDI in Economic Development. Nordic Journal of Political Economy, 28, 109-126.

Lall, S. (1980). Vertical Inter-Firm Linkages in LDCs: An Empirical Study. Oxford Bulletin of Economic and Statistic, 42(3), 203-226. https://doi.org/10.1111/j.1468-0084.1980.mp42003002.x

Lall, S. (1981). Transnationals, domestic enterprises and industrial structure in host LDCs: A survey. In I. Livingstone (Ed.), Development Economics and Policy Readings, Allen and Unwin, London.

Lall, S. (1982). The Emergence of Third world multinationals: Indian Joint ventures Overseas. World Development, 10(2), 127-146. https://doi.org/10.1016/0305-750X(82)90043-2

Latorre, M. C. (2008). Multinationals and Foreign Direct Investment: Main Theoretical strands and empirical effects. Research Working Paper, No. 1745, the World Bank.

Latorre, M. C., Bajo-Rubio, O., \& Gómez-Plana, A. G. (2008). The effects of MNES on Host Economies: A Computable General Equilibrium Approach. Working Paper No.4/08, Institutode Estudios Fiscales.

Lin, P., \& Saggi, K. (2004). Multinational Firms and Backward Linkages: A Critical Survey and a Simple Model. In M. Blomstrom, E. Graham, \& T. Moran (Eds.), The Impact of Foreign Direct Investment on Development: New Measures, New Outcomes, New Policy Approaches. Institute for International Economics, Washington DC.

Lipsey, R. E. (2002). Home and Host Country Effects of FDI. Working Paper No. 9293, National Bureau of Economic Research. https://doi.org/10.3386/w9293

Lipsey, R. E., \& Weiss, M. Y. (1981). Foreign Production and Exports in Manufacturing Industries. Review of Economics and Statistics, 63, 488-494. https://doi.org/10.2307/1935843

Lipsey, R. E., \& Weiss, M. Y. (1984). Foreign production and exports of individual firms. Review of Economics and Statistics, 66, 304-307. https://doi.org/10.2307/1925832

Markusen, J., \& Venables, A. (1999). Foreign Direct Investment as a Catalyst for Industrial Development. European. Economic Review, 43(2), 335-356. https://doi.org/10.1016/S0014-2921(98)00048-8

Ogbu, O. (2012). Towards Inclusive Growth in Nigeria. The Brookkings Institution 177 Massachusetts Ave., NW Washington, DC 20036. 
Paez, L. (2011). Liberalizing Financial Services and Foreign Direct Investment; Developing a Framework for Commercial Banking FDI. Palgrave Macmillan, Basingstoke, UK.

Phillips, P. C., \& Perron, P. (1988). Testing for a Unit Root in Time Series Regression. Biometrika, 75(2), 335-346. https://doi.org/10.1093/biomet/75.2.335

Prasanna, N. (2010). Direct and Indirect Impacts of Foreign Direct Investment on Domestic Investment. Indian Journal of Economics, 1(2), 77-83.

Rodríguez-Clare, A. (1996). Multinationals, Linkages, and Economic Development. American Economic Review, $86,852-873$.

Safdari, M., \& Motiee, R. (2011). Effects of Monetary Policy on Industry Sector Growth in Iran. European-journal, $1(4), 29-40$.

Smarzynska, J. B. (2004). Does foreign direct investment increase the productivity of domestic firms? In search of spillovers through backward linkages. American Economic Review, 94(3), 605-627. https://doi.org/10.1257/0002828041464605

Swenson, D. L. (2003). Overseas assembly and country sourcing choices, Working Paper No.10697, National Bureau of Economic Research.

Swenson, D. L. (2004). Foreign investment and mediation of trade flows. Review of International Economics, 12, 609-629. https://doi.org/10.1111/j.1467-9396.2004.00470.x

Szirmai, A. (2009). Industrialisation as an engine of growth in developing countries. UNU-MERIT Working Paper, 2009-013, Maastricht.

The World Bank. (2015). World Development Indicators 2015. Oxford University Press, USA. https://doi.org/10.1596/978-1-4648-0440-3

UNCTAD. (2004). World Investment Report (2004). The Shift Towards Services. United Nation, Geneva.

Wen, D. (2005). China Copes with Globalization - A Mixed Review. A Report by The International Forum on Globalization. San Francisco.

\section{Copyrights}

Copyright for this article is retained by the author(s), with first publication rights granted to the journal.

This is an open-access article distributed under the terms and conditions of the Creative Commons Attribution license (http://creativecommons.org/licenses/by/4.0/). 